\title{
PHOTOELASTIC RESEARCH OF THREE-DIMENSIONAL PROBLEMS OF FRACTURE MECHANICS
}

\section{Yuri Rudyak'; Mykola Pidgurskyi²; Iryna Matvieieva ${ }^{3}$; Valentyna Groza ${ }^{3}$; Viktor Sichкo $^{4}$; Volodymir Merzliuk ${ }^{5}$; Ivan Pidgurskyi ${ }^{2}$}

\author{
${ }^{1}$ I. Horbachevsky Ternopil National Medical University, Ternopil, Ukraine \\ ${ }^{2}$ Ternopil Ivan Puluj National Technical University, Ternopil, Ukraine \\ ${ }^{3}$ National Aviation University, Kyiv, Ukraine \\ ${ }^{4}$ V. O. Sukhomlynskyi National University of Mykolaiv, Mykolaiv, Ukraine \\ ${ }^{5}$ Antonov Company, Kyiv, Ukraine
}

\begin{abstract}
Summary. A polarization-optical method for studying three-dimensional problems of fracture mechanics has been developed. The method was tested to determine the values of stress intensity factors (SIF) for surface cracks in thin plates and thin shells. The data of SIF values for surface cracks of different geometry, which are subjected to different loadings, are obtained. The experimentally obtained values of SIF were compared with those calculated analytically. The efficiency of the proposed technique for solving the corresponding problems of engineering practice is shown.
\end{abstract}

Key words: fracture mechanics, stress intensity factor, photoelasticity, thin plates, thin shells.

Statement of the problem. The reliability of modern equipment and its functionality depends on the effective assessment of stress strain state (SSS) and the limit state of the elements of machines and structures, especially in the presence of geometric and technological concentrators. At present, such tasks can be efficiently solved by applying analytical and numerical methods. Modern computer technology allows simulating elements of machines and building structures with optimal geometry, minimum material consumption and increased reliability. Great strides have been made in computer simulation of fracture mechanics problems (processes of surface and through-cracks development, pre-fracture zones and «neck formation»). The results obtained analytically (and calculated numerically) have become the basis for creating a data bank when designing devices and components of machines. Nevertheless, with the undeniable success of analytical and numerical methods, there is a practical need for the development of experimental methods. Therefore, the more fully all factors are taken into account in the basic hypothesis, the more accurate the analytical solution is. Moreover, this problem is quite difficult to be solved for complex full-scale objects.

Analysis of available investigations and publications. The application of experimental methods in modern conditions is most effective in three areas: for the study of field objects; as test tasks in the development of new analytical methods; for obtaining experimental data, which, in combination with numerical methods, can increase the accuracy and reliability of analytical solutions [1-10]. Optical methods take a special place in experimental research methods [3,8-10]. Light as a probing tool provides a wide range of opportunities for the experimenter. In recent years, a number of new optical methods of experimental mechanics have been proposed $[8,10]$. At the same time, traditional classical 
research methods, such as polarization-optical or photoelasticity methods have significant potential $[3,8]$.

The objective of the paper - is to modify and develop modern approaches of the photoelasticity method for the most effective study of three-dimensional problems of fracture mechanics in thin-walled plate and shell structural elements.

Methods of research. Analytical and experimental studies are based on the provisions of solid-state mechanics and fracture mechanics, modern ideas about the physics of the interaction of light with the medium, basic equations of the parameters of the dialectric permeability tensor (DPT) and stress-strain state (SSS). The methods of three-dimensional photoelasticity using «deformation freezing» and microzonal photoelasticity are applied.

Epoxy resin models were investigated by polarization-optical method on coordinatesynchronous polarimeters КСП-7 and КСП-10. The kinetics of fracture of inorganic silicate glass was studied on aggregate polarization microscopes ПОЛАМ Р - 312 and ПОЛАМ Л - 211. The stress state of homogeneous and heterogeneous triplexes at low temperatures was investigated using a polarimeter КСП-7.

Main thesis. In $[8,10]$, a method was developed and formulas were obtained to determine the values of stress intensity factors (SIF) along the front of surface cracks in thinwalled structural elements using three-dimensional photoelasticity with deformations «freezing». For different arrangements of surface cracks relative to the direction of action of tensile stresses $\sigma$ (determined by the angle $\alpha$ - the angle between the frontal projection of the surface cracks and the direction of tensile stress $\sigma$ ) and the angle, at which the surface crack is located relative to the surface of the plate (angle $\beta$ - the angle between the side projection of surface crack mand the plane of the plate), the appropriate expressions to determine the values of SIF were obtained.

All these expressions for determining the value of SIF are proposed to be written by one general formula (1), which contains constants A1, A2, A3. The constants for each of the main types of the crack edges deformation and the presence of the corresponding SIF values will take certain values.

$$
K_{i}=A_{1} \frac{\sqrt{\pi r}}{C d} \cdot\left[A_{2}\left(\delta^{\prime} \sin 2 \varphi^{\prime}-\delta^{0} \sin 2 \varphi^{0}\right)+A_{3}\left(\delta^{\prime} \cos 2 \varphi^{\prime}-\delta^{0} \cos 2 \varphi^{0}\right)\right]
$$

$i=\mathrm{I}, \mathrm{II}, \mathrm{III}$

In the formula (1):

$r$-radius vector of the point of the optical quantities measurement, which is measured from the crack tip on the corresponding section or sub-section;

$C$ - optical constant of the model material based on epoxy resin ЕД-20M;

$d$-thickness of the section or sub-section;

$\delta^{\prime}$ - optical path difference of the rays, which characterizes the parameters of the general stress state near the crack tip;

$\varphi^{\prime}$ - isocline parameter, which characterizes the parameters of the general stress state near the crack tip;

$\delta^{0}$ - optical path difference of the rays, which characterizes the parameters of the base stress state;

$\varphi^{0}$-isocline parameter, which characterizes the parameters of the ground stress state.

Let us consider the possible options for the location of the surface crack in the plate and the corresponding stress fields near the contour of the cracks.

The options for the location of surface cracks in the plates under tension and the corresponding values of constants $A_{1}, A_{2}, A_{3}$ in determining the values of SIF by formula (1) are presented below. 


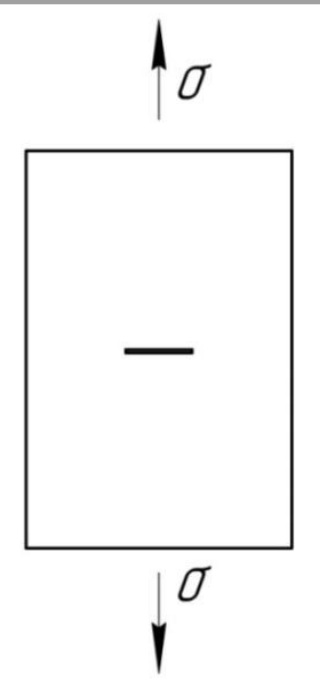

a)

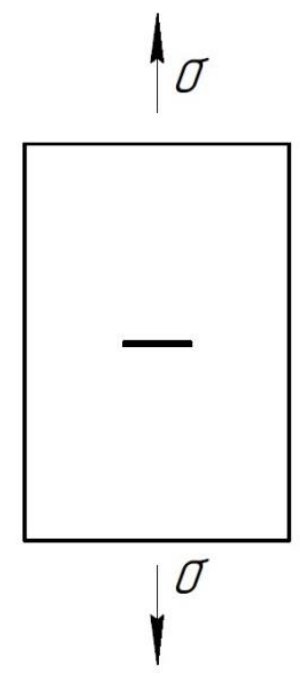

c)

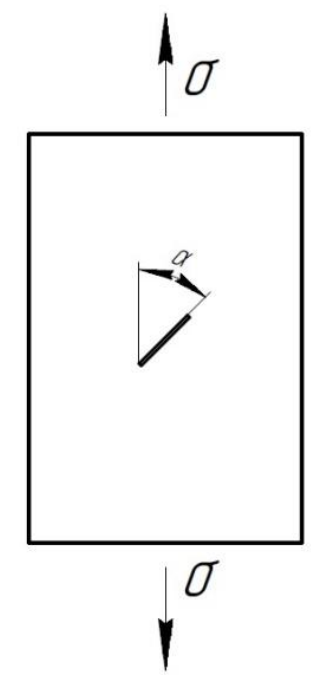

b)

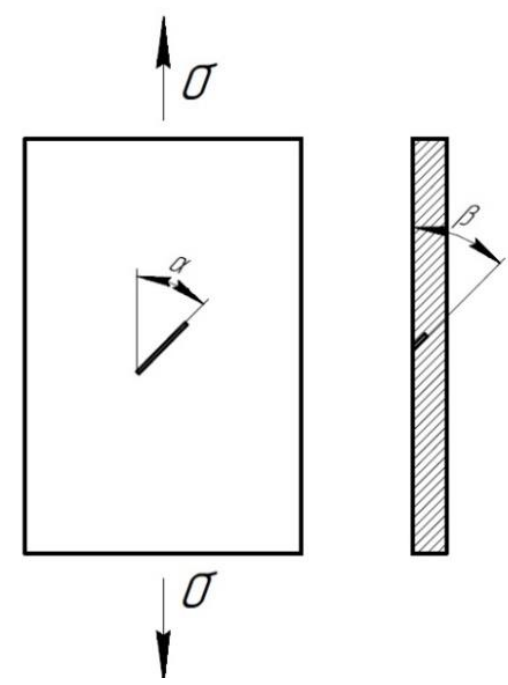

d)

Figure 1. Deformation around the tip of the surface crack: a) type I; b) type I and type II; c) type I and type III; d) type I, type II, and type III - crack opening

The stress state around the contour (Fig. 1, a) corresponds to type I of deformation $\left(K_{\mathrm{I}}\right)$. Constants $A_{i}$ in formula (1) take the values $A_{1}=-2 ; A_{2}=0 ; A_{3}=1$.

Formula (1) takes the form (2):

$$
K_{\mathrm{I}}=-\frac{2 \sqrt{\pi r}}{C d}
$$

The stress state around the contour (Fig. 1, b) corresponds to types I and II of deformation ( $K_{\mathrm{I}}$ and $\left.K_{\mathrm{II}}\right)$. Constants $A_{i}$ in formula (1) take the values

$K_{\mathrm{I}} \quad: A_{1}=-1 ; A_{2}=A_{3}=1$.

$K_{\mathrm{II}} \quad: A_{1}=A_{2}=1 ; A_{3}=-1$.

Formula (1) takes the form of formulas (3) and (4):

$$
K_{\mathrm{I}}=-\frac{\sqrt{\pi r}}{C d} \cdot\left[\left(\delta^{\prime} \sin 2 \varphi^{\prime}-\delta^{0} \sin 2 \varphi^{0}\right)+\left(\delta^{\prime} \cos 2 \varphi^{\prime}-\delta^{0} \cos 2 \varphi^{0}\right)\right]
$$




$$
K_{\mathrm{II}}=\frac{\sqrt{\pi r}}{C d} \cdot\left[\left(\delta^{\prime} \sin 2 \varphi^{\prime}-\delta^{0} \sin 2 \varphi^{0}\right)-\left(\delta^{\prime} \cos 2 \varphi^{\prime}-\delta^{0} \cos 2 \varphi^{0}\right)\right]
$$

The stress state around the contour (Fig. 1, c) corresponds to type I and III of deformation $\left(\mathrm{K}_{\mathrm{I}}\right.$ and $\mathrm{K}_{\mathrm{III}}$ ). Constants $A_{i}$ in formula (1) take the values

$K_{\mathrm{I}} \quad: A_{1}=-2 ; A_{2}=0 ; A_{3}=1$.

$K_{\text {III }} \quad: A_{1}=A_{2}=1 ; A_{3}=0$.

Formula (1) takes the form of formulas (5) and (6):

$$
\begin{gathered}
K_{\mathrm{I}}=-\frac{2 \sqrt{\pi r}}{C d} \cdot\left[\left(\delta^{\prime} \cos 2 \varphi^{\prime}-\delta^{0} \cos 2 \varphi^{0}\right)\right] ; \\
K_{\mathrm{III}}=\frac{\sqrt{\pi r}}{C d} \cdot\left[\left(\delta^{\prime} \sin 2 \varphi^{\prime}-\delta^{0} \sin 2 \varphi^{0}\right)\right]
\end{gathered}
$$

The stress state around the contour (Fig. 1, d) corresponds to all 3 types of deformation ( $\left.K_{\mathrm{I}}, K_{\mathrm{II}}, K_{\mathrm{III}}\right)$. Constants $A_{i}$ in formula (1) take the values

$\begin{array}{ll}K_{\mathrm{I}} & : A_{1}=-1 ; A_{2}=A_{3}=1 . \\ K_{\mathrm{II}} & : A_{1}=A_{2}=1 ; A_{3}=-1 . \\ K_{\text {III }} & : A_{1}=A_{2}=1 ; A_{3}=0 .\end{array}$

Formula (1) takes the form of formulas (3), (4) and (6), respectively.

\section{Results of the research.} structures.

1. Experimental determination of SIF values for surface cracks in thin-walled

\subsection{Determination of SIF $K_{\mathrm{I}}$ and $K_{\mathrm{II}}$.}

1. The model with a crack is «frozen» under the action of working load (fig. 2).

2. From the «frozen» model, rows of sections are cut, along the normal to the crack front (Fig. 3)

3. On the coordinate-synchronous polarimeter КСП -10 along the line $\theta=90^{\circ}$, measurements of the optical path difference of polarized rays $\delta^{\prime}$ of the isocline parameter $\varphi^{\prime}$ are carried out for the relations: $0.2 \leq r / a \leq 0.4$, where $r$ is the radius vector of the point of measurement of general stress state parameters; $a$ is the depth of the surface crack for this section; $d_{1}$ is the thickness of the section; $r^{\circ}$ is the radius vector of the point of measurement of the base stress state parameters (Fig. 4).

The value of the ratio $0.2 \leq r / a \leq 0.4$ is the "confidence interval" determined experimentally. In this interval, the values of SIF are calculated according to the proposed formulas and based on photoelastic measurements, which characterize the additional stress state, practically do not change their values.

4. On the same device, a difference of the course $\delta^{\circ}$ and the isocline parameter $\varphi^{\circ}$ for relations $2 \leq r \% a \leq 2.5$ are measured (fig. 4). The optical quantities that characterize the parameters of the base stress state are measured in the interval $2 \leq r \% a \leq 2.5$. There is no complete optical picture of the additional stress state at the crack tip.

5. Based on the result of measurements, the values $K_{\mathrm{I}}$ (symmetrical distribution of stresses relative to the edges of the cracks in the section plane) by formula (2) are determined.

6 . The values of $K_{\mathrm{I}}$ and $K_{\mathrm{II}}$ (with asymmetric stress distribution relative to the crack edges in the section plane) by formulas (3) and (4) are determined. 


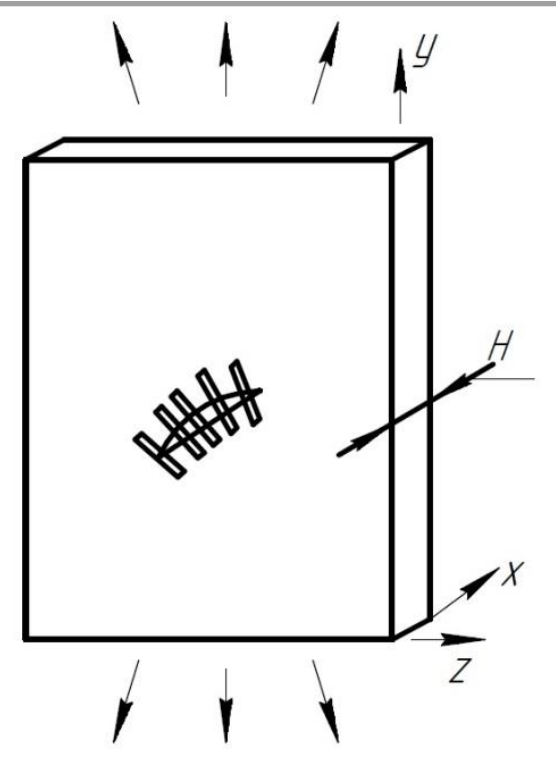

Figure 2. «Freezing» of the model with a surface crack under load

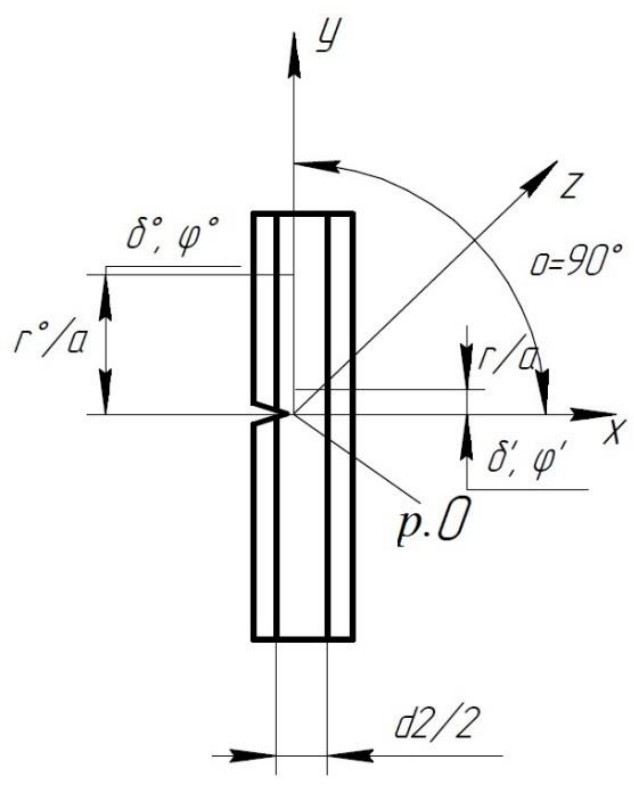

Figure 4. Determination of the SIF values $K_{\mathrm{I}}$ and $K_{\mathrm{II}}$ on sections normal to the crack front

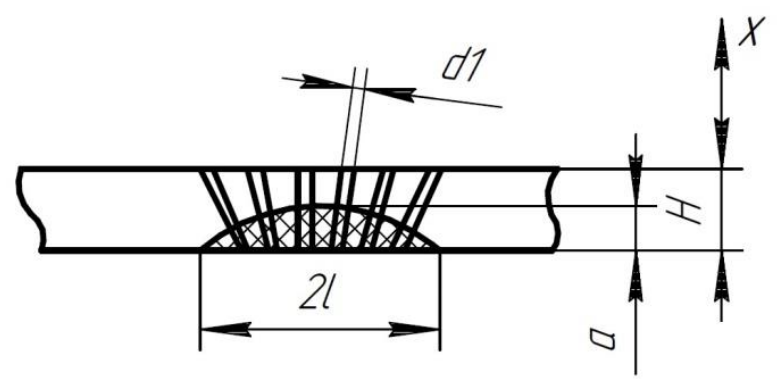

Figure 3. Location scheme of the crack sections

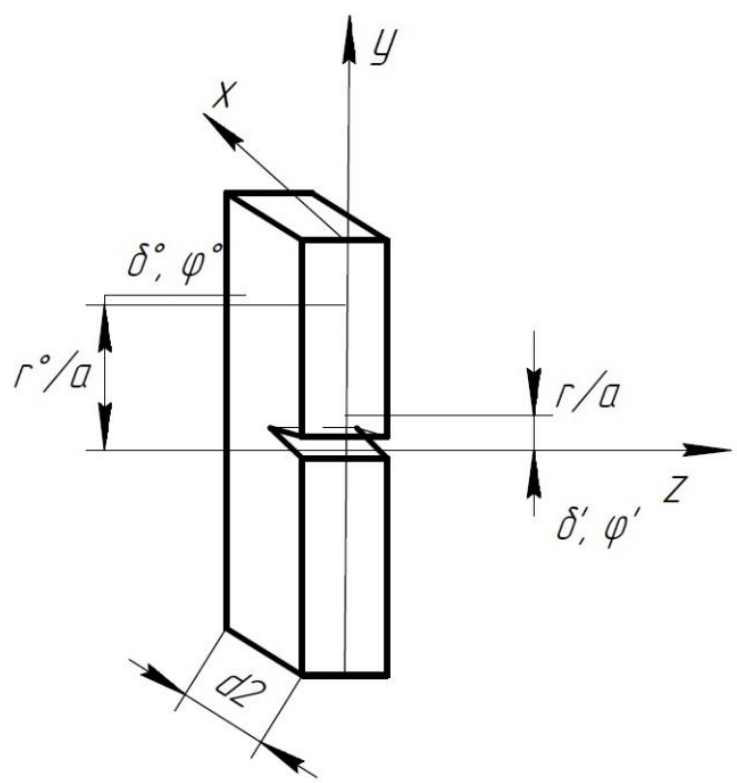

Figure 5. Determination of the SIF values $K_{\text {III }}$ on subsections that contain the crack tip

\subsection{Determination of $K_{\text {III }}$}

1. The model with a crack is «frozen» under the action of the working load (Fig. 2).

2. From the «frozen» model, rows of sections are cut, along the normal to the crack front (definition of $K_{\mathrm{I}}$ and $K_{\mathrm{II}}$ ). (Fig. 3, Fig. 4).

3. Sub-sections are cut from the sections so that the crack tip is in the middle of the thickness of the sub-section and the ratio $d_{2} / a=0.5$ is fulfilled, where $a$ is the depth of the surface crack for this section; $d_{2}$ is the thickness of the sub-section.

4. On the coordinate-synchronous polarimeter КСП -10, the measurements of $\delta^{\prime}, \varphi^{\prime}, \delta^{\circ}$, $\varphi^{\circ}$ are carried out at the ratios $0.2 \leq r / a \leq 0.4 ; 2 \leq r \% a \leq 2.5$.

5. Based on the measurement results, the value of $K_{\text {III }}$ by formula (6) is determined. 
As the crack depth decreases, its impact zone decreases as well. Thus, the effect of a crack with a depth of $a=1 \mathrm{~mm}$ in a thin plate with a wall thickness of $H=2.3 \mathrm{~mm}$ is not completely visible at a distance of $r^{\circ}=2.5 \mathrm{~mm}$. The ratio $r \% a$, which is given in the description of the method, was determined by the picture of isochromatic fringes - a field uniform in intensity, starting from the crack tip, which satisfies the above ratio $r^{o} / a$; by measuring the optical path difference $\delta$ of polarized rays and the isocline parameter $\varphi$ by the method of compensation (starting from this distance $\varphi$ and $\delta$ take constant values - for a plate with a crack under tension, for a number of cracks of different depth). The ratio $d_{2} / a$ is obtained by determining the «confidence interval», ie the area near the crack tip, in which the obtained values of the SIF have a constant value.

Thus, for thin-walled structures, we have the opportunity to determine the parameters of the base stress state at a distance very close to the crack tip, which helps to increase accuracy. For high-gradient stressed fields, the ground stress state can be defined as the average of these two measurements made at points symmetrical about the crack tip at the cut. Determining the value of $K_{\text {III }}$ on sub-sections containing the crack tip makes the method usable for the study of thin-walled structures, as neither a series of thin sections («chip method») nor measurement at a section close to the crack tip («thin section method»), which are given in [3], are not applicable to determine the value of $K_{\text {III }}$ in thin plates and shells due to their small thickness.

The optical path difference of the polarization rays $\delta$ and the isocline parameter $\varphi$ when determining the value of SIF is measured in such a way that the condition formed on the sections and subsections: the angle formed by the crack plane and the line connecting the crack tip with the measurement points should be equal to $90^{\circ}$. This increases the accuracy of measurements, as the fulfilment of this condition will not depend on the accuracy of the coordinator of the device КСП -10. In addition, measurements at an angle of $90^{\circ}$ greatly simplify the final formulas for calculating SIF values. The deep cracks in thin-walled structures $(a / h \geq 0.8)$ cannot be measured at an angle $\theta<90$ due to the proximity of the crack contour to the wall of the plate.

\section{Comparison of experimental data with calculations.}

The proposed method for determining the SIF for surface cracks in thin-walled structures was tested on flat models (plates) and three-dimensional models (shells).

Experimentally found SIF values were compared with known theoretical solutions of the corresponding problems [1].

Under study: a) semi-elliptical surface crack in a thin plate located perpendicular to the line of action of tensile forces; b) semi-elliptical surface crack in a thin closed shell, loaded by the action of internal pressure, which is located along the shell; c) rectangular surface cracks in a thin shell exposed to torque, located along the forming shell. The optical path difference $\delta$ and the isocline parameter $\varphi$ in the region of all investigated cracks were measured on the instrument КСП -10.

In Fig. 6, pictures of isochromatic fringes in the «frozen» section of the surface crack are shown. The results of experimental research (solid lines) and their comparison with the theoretical values calculated according to the literature are given below in the form of graphs in Fig. 7-9. 

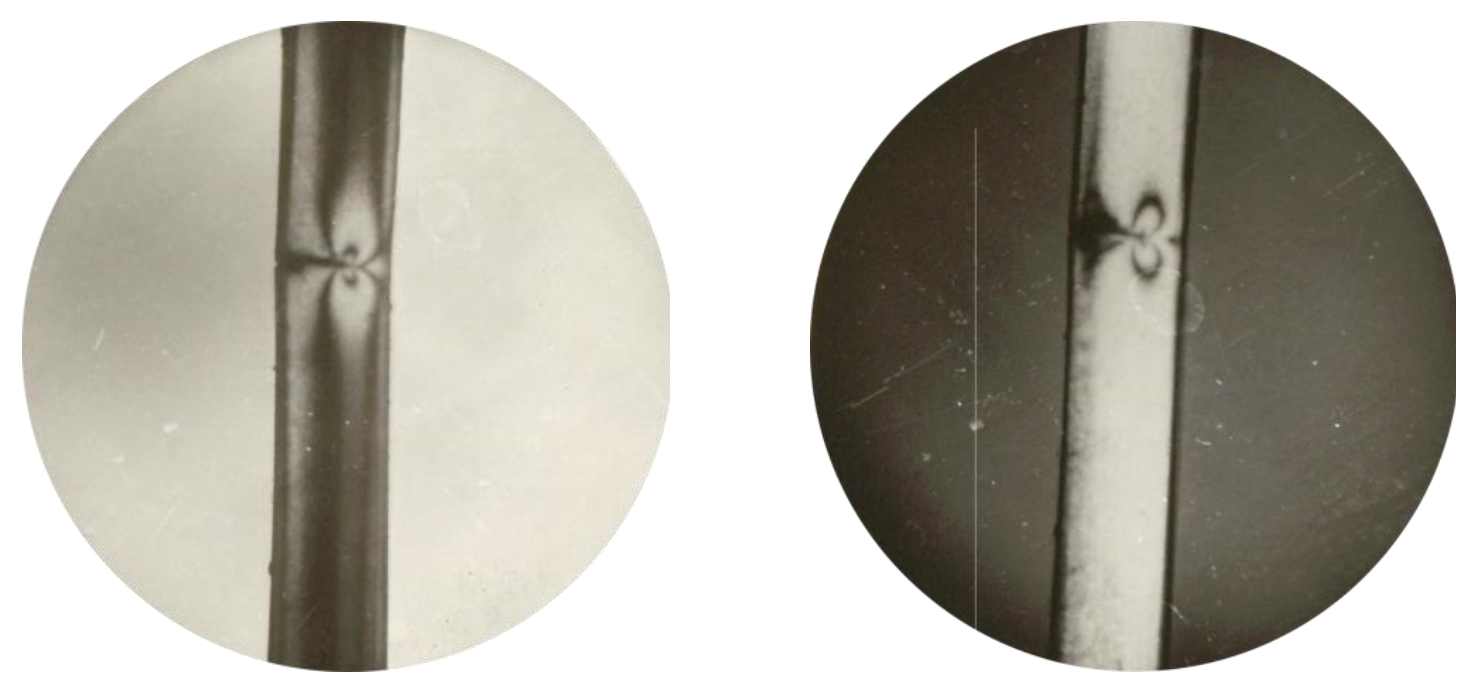

Figure 6. Pictures of isochromatic fringes in the section containing the point of maximum deepening of semi-elliptical surface crack in the plate under tension
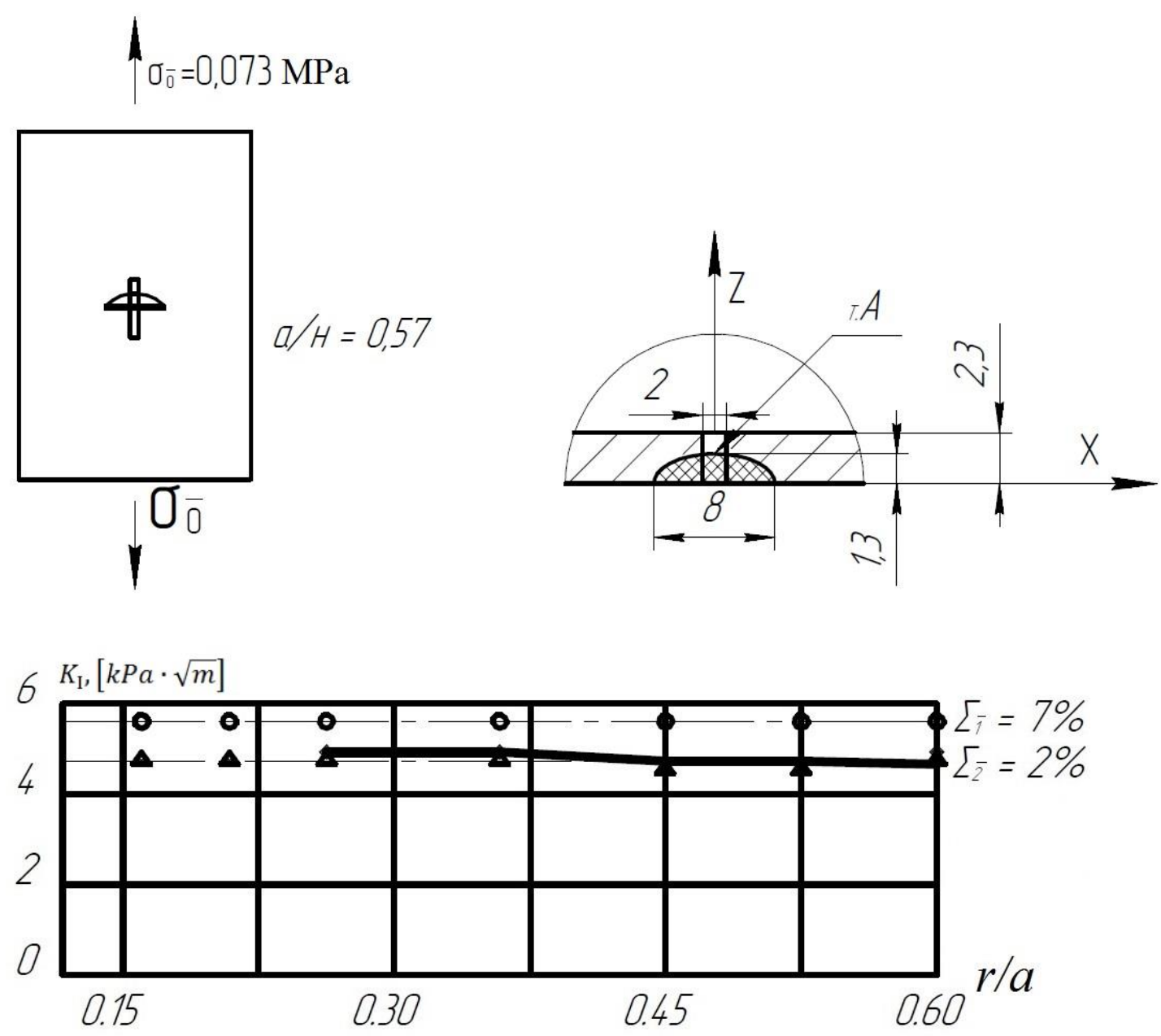

Figure 7. Determination of the SIF value $K_{\mathrm{I}}$ at the deepest point of the semi-elliptical surface crack front in thin plate under tension 

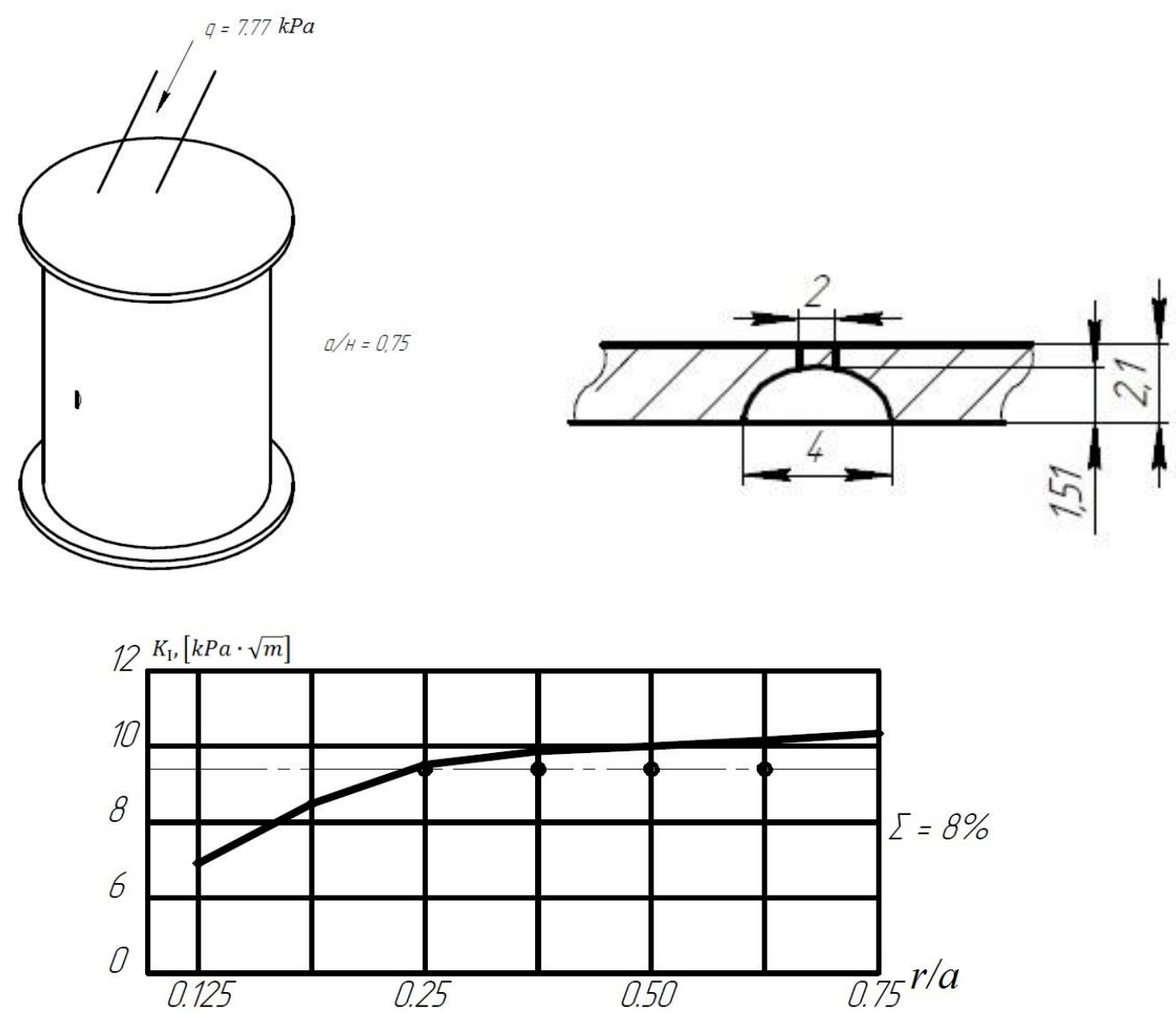

Figure 8. Determination of the SIF value $K_{\mathrm{I}}$ at the deepest point of the front of the semi-elliptical surface crack front in a closed thin shell loaded by the internal pressure (the crack is located along the shell)
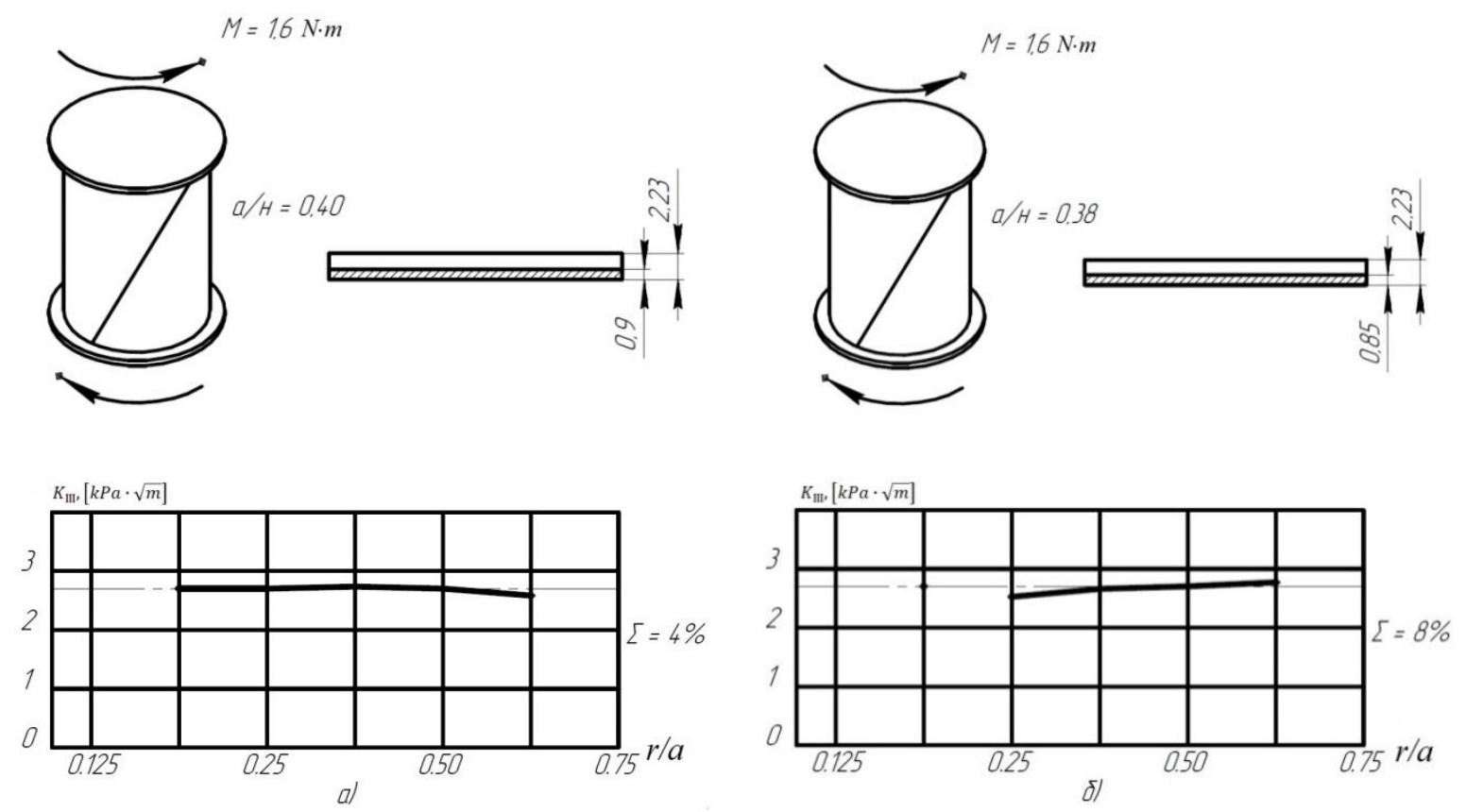

Figure 9. Determination of the SIF value $K_{\text {III }}$ for rectangular surface cracks in a thin shell, which is subjected to torque 
Conclusions. Based on the analysis results of experimental data comparison for determining the SIF values for surface cracks with theoretical ones, the discrepancy is from $2 \%$ to $8 \%$. Therefore, the developed method for studying the three-dimensional problems of fracture mechanics according to photoelastic analysis provides the necessary accuracy and can be used for the analysis of thin-walled structures with non-through cracks.

The main essence of the developed and experimentally implemented method of measuring the SIF values for surface cracks in thin-walled plate and shell structures is to determine separately the optical parameters that characterize the general and basic stress states. Based on this information, the access to the additional stress state parameters is provided, which includes the SIF values, and, based on the obtained experimental information, the SIF values $K_{\mathrm{I}}, K_{\mathrm{II}}, K_{\mathrm{III}}$ are determined.

The «confidence interval» $r / a=0.2 \div 0.6$ is determined, in which the experimentally determined SIF values according to the data of photoelastic studies coincide as much as possible with the calculated data.

\section{References}

1. Timoshenko S., Goodier J. N. (2010) Theory of elasticity, 3rd edn. McGraw-Hill, New York City.

2. Zhang X., Hao H., Shi Y., Cui J. (2015) The mechanical properties of polyvinyl butyral (PVB) at high strain rates. Constr. Build. Mater. 93, 404-415. DOI: https://doi.org/10.1016/j.conbuildmat.2015.04.057

3. Aben H., Guillemet C. (1993) Photoelasticity of Glass. Springer, Berlin. DOI: https://doi.org/10.1007/978-3-642-50071-8

4. Awaja F., Zhang S., Tripathi M., Nikiforov A., Pugno N. (2016) Cracks, microcracks and fracture in polymer structures: Formation, detection, autonomic repair. Prog. Mater. Sci. 83, 536-573. DOI: https://doi.org/10.1016/j.pmatsci.2016.07.007

5. Wang Q., Chen H., Wang Y., Sun J. (2013) Thermal shock effect on the glass thermal stress response and crack propagation. Procedia Eng. 62, 717-724. DOI: https://doi.org/10.1016/j.proeng.2013.08.118

6. Fröling M., Persson K., Austrell P. E. (2014) A reduced model for the design of glass structures subjected to impact loads. Eng. Struct. 80, 53-60. DOI: https://doi.org/10.1016/j.engstruct.2014.08.043

7. Weller B., Wünsch J., Härth K. (2005) Experimental study on different interlayer materials for laminated glass. In: Conference: Glass Processing Days, Tampere, pp. 120-123.

8. Rudyak Yu., Pidgurskyi M. Opticheskie metody mekhaniki tverdogo tela. Saarbrücken, Deutschland: LAP LAMBERT Academic Publishing, 2015. 128 p. [In Russian].

9. Pidgurskyi M., Rudyak Yu. Pidgurskyi I. (2019). Research and Modeling of Stress-Strain State and Fracture Strength of Triplexes at Temperatures 293-213K. // Lecture Notes in Mechanical Engineering SerProceedings of the 7th International Conference on Fracture Fatigue and Wear., Belgium, Ghent University, 2018. P. 135-150. DOI: https://doi.org/10.1007/978-981-13-0411-8_14

10. Rudyak Yu., Pidgurskyi M. Optychni eksperymentalno-rozrakhunkovi metody vyznachennia NDS ta hranychnoho stanu bahatosharovykh struktur z kontsentratoram. Visnyk Ternopilskoho natsionalnoho tekhnichnoho universytetu. № 1. 2014. P. 11-21. [In Ukrainian].

\section{Список використаної літератури}

1. Timoshenko S., Goodier J. N.: Theory of elasticity, 3rd edn. McGraw-Hill, New York City, 2010.

2. Zhang X., Hao H., Shi Y., Cui J. The mechanical properties of polyvinyl butyral (PVB) at high strain rates. Constr. Build. Mater. 2015. 93, 404-415. DOI: https://doi.org/10.1016/j.conbuildmat.2015.04.057

3. Aben H., Guillemet C. Photoelasticity of Glass. Springer, Berlin, 1993. DOI: https://doi.org/10.1007/978-3-642-50071-8

4. Awaja, F., Zhang, S., Tripathi, M., Nikiforov, A., Pugno, N.: Cracks, microcracks and fracture in polymer structures: Formation, detection, autonomic repair. Prog. Mater. Sci. 83, 536-573 (2016). DOI: https://doi.org/10.1016/j.pmatsci.2016.07.007

5. Wang Q., Chen H., Wang Y., Sun J. Thermal shock effect on the glass thermal stress response and crack propagation. Procedia Eng. 2013. 62, 717-724. DOI: https://doi.org/10.1016/j.proeng.2013.08.118

6. Fröling M., Persson K., Austrell P. E. A reduced model for the design of glass structures subjected to impact loads. Eng. Struct. 2014. 80, 53-60. DOI: https://doi.org/10.1016/j.engstruct.2014.08.043

7. Weller B., Wünsch J., Härth K. Experimental study on different interlayer materials for laminated glass. In: Conference: Glass Processing Days, Tampere, 2005, p. 120-123.

8. Рудяк Ю., Пидгурский Н. Оптические методы механіки твердого тела. Saarbrücken, Deutschland: LAP LAMBERT Academic Publishing, 2015. 128 p. ISBN 978-3-659-69350-2. 
9. Pidgurskyi M., Rudyak Yu., Pidgurskyi I. (2019). Research and Modeling of Stress-Strain State and Fracture Strength of Triplexes at Temperatures 293-213K. Lecture Notes in Mechanical Engineering SerProceedings of the 7th International Conference on Fracture Fatigue and Wear., Belgium, Ghent University, 2018. P. 135-150. DOI: https://doi.org/10.1007/978-981-13-0411-8_14

10. Рудяк Ю., Підгурський М. Оптичні експериментально-розрахункові методи визначення НДС та граничного стану багатошарових структур 3 концентраторам. Вісник Тернопільського національного технічного університету. № 1. 2014. С. 11-21.

\title{
УДК 539.378
}

\section{ФОТОПРУЖНЕ ДОСЛІДЖЕННЯ ПРОСТОРОВИХ ЗАДАЧ МЕХАНІКИ РУЙНУВАННЯ}

\section{Юрій Рудяк'; Микола Підгурський²; Ірина Матвєєва Валентина Гроза³ ; Віктор Січко ${ }^{4}$; Володимир Мерзлюк5; Іван Підгурський ${ }^{2}$}

${ }^{1}$ Тернопільський національний медичний університет імені І. Я. Горбачевського, Тернопіль, Україна

${ }^{2}$ Тернопільський національний технічний університет імені Івана Пулюя, Тернопіль, Україна

${ }^{3}$ Національний авіаційний університет, Київ, Украӥна

${ }^{4}$ Миколаївський національний університет імені В. О. Сухомлинського, Миколаїв, Україна БДП «АНТОНОВ», Київ, Украӥна

\begin{abstract}
Резюме. Розвинуто поляризаційно-оптичний метод дослідження тривимірних задач механіки руйнування. За даними фотопружних вимірювань запропоновано визначати окремо параметри загального та основного напружених станів, і на основі отриманих даних розраховувати параметри додаткового напруженого стану, в які входять коефіцієнти інтенсивності напружень (КІН). Такий підхід дозволяє визначити КІН для невеликих за величиною картин оптичної анізотропї, які характерні для поверхневих тріщин у тонких пластинах і оболонках, виготовлених із оптично-чутливих матеріалів на базі епоксидної смоли, неорганічного силікатного скла та у гомогенних і гетерогенних триплексах. Параметри загального напруженого стану вимірюються поблизу околу тріщин, у так званому «інтервалі достовірності», в якому експериментально визначені величини КІН для різних радіус-векторів точок вимірювання, практично не відрізняються між собою. Параметри основного напруженого стану визначаються на певних відстанях від фронту тріщини, для яких оптична інтерференційна картина не містить зон концентрації напружень. Запропоновано загальну формулу для визначення КІН таким шляхом для різних видів деформацї в околі тріщини. Формула містить коефіцієнти, які набувають певні значення залежно від наявності поблизу околу тріщини КIH KI, KII, KIII, або їх комбінацій. Метод експериментально реалізований за допомогою об'ємної фотопружності із «заморожуванням» деформаџій та поляризаџійно-оптичним дослідженням зрізів $i$ субзрізів поверхневих тріщин. Метод апробовано при визначенні величин КІН для поверхневих тріщин у тонких пластинах і оболонках, виготовлених із оптично-чутливого матеріалу на базі епоксидно-діанової смоли ЕД-20М. Отримано дані величин КІН для поверхневих тріщин різної геометрії в плані (півеліптичних, прямокутних), які перебувають при різних видах навантаження. Розглянуто пластини з поверхневими тріщинами при розтягу, тонкі оболонки з поверхневими тріщинами під дією внутрішнього тиску та кручення. Експериментально отримані величини КІН порівнювали з розрахованими значеннями, обчисленими за відомими залежностями. Розбіжність експериментально отриманих величин КІН із розрахованими аналітично складає 2-8\% для різних варіантів розташування поверхневої тріщини, ї̈ геометрії та виду навантаження тонких пластин і оболонок. Показано ефективність запропонованої методики визначення КІН за картинами оптичної анізотропї невеликої величини для розв'язання відповідних задач інженерної практики.
\end{abstract}

Ключові слова: механіка руйнування, коефіцієнт інтенсивності напружень, фотопружність, тонкі пластини, тонкі оболонки. 